\title{
Just Talk?
}

\section{Anthropological Reflections on the Object of Media Studies in Indonesia}

\author{
Mark Hobart \\ School of Oriental and African Studies (SOAS) \\ University of London
}

\begin{abstract}
This article sets out to reflect critically on the object of study in media and communication studies. It argues that not only the conventional analytical categories but also the modes of explanation and interpretation used are both problematic and Eurocentric, because they are mediated by a whole series of industrial and intellectual practices which have remained unacknowledged. The article aims to show how taking media-related practices as an object of study, requires radical revision to much of media studies. Central among these practices is commentary of various kinds. The mass media spend much time commenting on themselves and one another, just as research through questionnaires, focus groups and interviews are invitations to participants to comment. Commenting in its many forms emerges therefore as an important way of indicating how articulation, a central concept in media and cultural studies, works. Drawing on examples from Indonesia, an analysis of commentary provides a way of understanding how audiences relate to media production, not least because people talk about the mass media and how they are implicated, or perhaps even disarticulated by the media. In failing to appreciate how commentary works, media scholars are complicit in this process of disarticulation, a notion elaborated in the article.
\end{abstract}

In the summer of 1997, I was involved in a number of conversations with a group of Balinese villagers about how contemporary mass media was affecting their lives — a topic upon which people wax lyrical. One evening the discussion took an interesting turn. Let me give brief extracts. ${ }^{1}$

1 The evening's discussion is laid out and analyzed at length in Hobart (1999a). For exposition here, I have edited the dialogue, which involved three principal speakers. These were an ex-headman of the village where I work, an old theatre actor (now in his nineties) and a female actress-dancer in her late twenties and the daughter-in-law of the ex-headman. The fact that all three are actors is not coincidental, for reasons which will become apparent.

This paper was originally presented to an AMIC-SCS-SOAS conference on Media, Practice, Antagonisms: Rethinking the Role of Mass Communication Researchers in Asia at Nanyang Technological University, Singapore 11-12th. June 1999.

My thanks to the anonymous reader for The Asian Fournal of Social Science, who made valuable comments on the original draft of this article. 
An Ex-Village Headman: If you ask my opinion, if things carry on for a long time like this. Our grandchildren will be in difficulties, if there isn't - what do you call it? ...

\section{An Old Actor:}

Self:

Actor:

Self:

Ex-Head:

Self:

Ex-Head:

Actor:

Ex-Head:

Actor:

Ex-Head:

Actor:

Ex-Head:

Actor:

Ex-Head:
Turmoil. If there isn't turmoil, so that everything starts afresh...

What do you mean by 'turmoil'?

It is everything turned upside down, destruction. But what's the use of a war?

Its use is that everything starts all over again. After a fresh beginning things are ordered again... You can't get, as you do now, people 'buffaloing'.

What's 'buffaloing'?

It's a proverb: those who are already too big just get bigger. Ordinary people can do nothing.

It's already too late. They can't lift a finger. For example, they're like tiny insects, they count for nothing. Even if I spoke up and said this or that, no one would pay any attention.

The poor are useless. No one believes them. The rich never think of actually talking with the poor. If possible, they keep as far away from them as they can, where the rich can talk among themselves about whatever. I don't think that the poor could succeed in speaking. Even if they did, they are worth nothing, no one is listening.

They show the good life on television. They provide images of beautiful things, so that those without will strive for them. The only problem is that they can't succeed.

They haven't the wherewithal.

Yes, it's hard. Why? You can say people these days, it's like advertisements. Why should government promote television the whole time and only broadcast what comes across as good? But what's bad is not, or is rarely, shown. The theory is fine...

But the practice is a very far cry from that. The practice is rotten. It is tantalizing the 
Actor:

Ex-Head: masses, goading them on, so that they will want to slave away.

So that they'll be joyful, for example so that they will do what they're told is right.

Yes. But afterwards there is the practice, which is different. For example, consider people going on transmigration programmes. They never show transmigrants starving. It's always people who...

Actor:

Young Dancer:

Ex-Head:
Who are happy.

'Successful'!

Just the ones who have made it. A lot of people have been duped that way.

Among the points the commentators made were that serious unrest was not just impending, but necessary to rectify the excessive inequalities between people. The relationship between the élite and ordinary people had broken down irremediably. There was no connection between the political rhetoric and images disseminated on television and how the élite operated in practice. The poor were not just dispossessed, but had been rendered inarticulate. Mass communication, on this account, was mass miscommunication and the silencing of the masses.

When I wrote the original analysis of these conversations for a collection on the impact of globalization in Bali in the late twentieth century (Hobart 1999a), it was politely received and put as the last chapter, a sort of appendix to the more serious matters of Bali's place in contemporary Indonesia. After all, what did the musings of a few Balinese villagers really add up to? As the volume was going to press a year later, the riots in Indonesia happened which led to the fall of Suharto and the New Order régime. So the publishers suddenly became anxious for more details. What the commentators had to say was no longer a mere ethnographic curiosity: they had predicted what the mass media and most serious intellectual authorities had failed to. Moreover, these villagers had anticipated much of the subsequent media commentary within Indonesia and abroad, which relegates the vast majority of the population as 'masses' or 'the poor', who have to be spoken for because they are - or, rather, have been rendered inarticulate.

\section{Why Anthropology?}

The problem of how to imagine, study and engage with 'the masses' in mass media takes us straight to a constitutive problem in media studies. Namely it is not a single discipline, but a site of contestation among diverse 
approaches across the human sciences, which reveals the incompatibility between them. The conjunction of media and communications studies disguises inherent antagonisms, which split many academic departments.

For convenience, we may trace the emergence of mass communications studies to the post-World War II period, when the European model of empire was being supplanted by the American dream of a modern consumer society. The imperative of communicating the message of modernity and how to achieve it engaged the obvious, and appropriately positivistic, disciplines of sociology and psychology. They drew upon a muscular, realisticsounding and so convincing rhetoric from political economy, which neatly, but not accidentally, dove-tailed with the agendas of western governments and corporations. It was in part in opposition to this triumphalist grand narrative of the new American imperium that cultural and media studies developed in post-imperial Britain to question these myths of capital and power. As much a series of intellectual arguments informed by postGramscian thinking and punctuated by formative ruptures as it was a conventional 'discipline' (Hall 1996), cultural studies, with a distinctive culturalist turn, and its empirical or ethnographic off-shoot, media studies, attracted attention from feminism and literary criticism inter alia. Cultural anthropology, which thought that it owned the franchise on 'culture', has largely stayed aloof and indeed ignorant of what was happening, apart from a handful of anthropologists who recognized the climactic change going on. ${ }^{2}$ How have all these different disciplines, each with distinct intellectual histories, formative debates, presuppositions and ways of conducting business, co-existed and contributed to a broader understanding of mass media around the world at this gargantuan intellectual fest?

Unfortunately, instead of acknowledging that the mass media comprise so complex, diverse and changing a congeries of institutions, practices and human subjects as to be beyond the scope of any single approach, human scientists have mostly settled back to doing what they do best coincidentally reminiscent of Orientalist accounts of Hindu-Buddhist kings. That is they have dreamed up scenarios in which they (and their disciplines) are sovereign, a source of enlightenment and central to the known world, while all others are subordinate, marginal or irrelevant. One discipline however positions itself as dominant. In effect the late-comers, the culturalists, literary critics and feminists, constitute oppositional voices to the entrenched mass communication specialists. Significantly, the rival theoretical positions reflect deep divisions in the history of philosophy of the human sciences themselves. Mass communications appeals to a vision of

2 The editors of Public culture in Chicago and (then) lone figures like Faye Ginsburg and Debra Spitulnik had recognized the importance for anthropology of cultural and media studies respectively. 
social science, which aims to replicate the rigour of theory and method of the natural sciences. The language is of facts, testing hypotheses and methodologies, which is attractive to governments, corporations and funding bodies who want to be able to present the world as tidy, measurable and so knowable, and under control.

The problem is this vision of natural science is a nineteenth-century idealization of both the nature of theory and scientific practice, as philosophers and historians of science have long noted. It is with the shortcomings of attempts to scientize the complexity, diversity, historicity and even contingency of media practice that alternative approaches have taken issue. As the philosophical arguments upon which these approaches draw is precisely the later critique of hegemonic naturalism, it is hardly unsurprising that the outcome is antagonistic. While cultural and media studies scholars like to present themselves as the radical vanguard, ironically, as Chen Kuan-Hsing has pointed out (1996), they in turn have extraordinary difficulty in seriously engaging with more radical French post-structuralism.

Where does anthropology come into all this? If we recognize that, realistically, no single discipline can adequately encompass so widespread and general a phenomenon as the mass media, then anthropologists are potentially qualified to contribute in several ways. The one which concerns me here is with rethinking the object of study.

Political economic and sociological macro-models were never designed to address production, distribution or reception treated as practices, nor the lived daily worlds of journalists, broadcasters, readers or viewers, nor the complex social contexts in which the media work. In short 'the mass media' are essentialized out of a gamut of media-related practices, which remain effectively unstudied. While macro-level analyses of global and national media industries may provide useful descriptions, they are largely unempirical and mediated. That is they are high level and potentially problematic abstractions from observable practice. Crucially they involve intermediate objects - for example 'the average' (Hacking 1990) in order even to start imagining audiences (hence the legendary problems of 'audience studies'). In a serious sense, the economy, the polity, media industries, globalization, indeed the entire vocabulary of mass communication is itself mediated, because such terms are not natural entities but the products of, and inextricable from, innumerable acts of commentary by politicians, industrialists, financiers, media commentators and academics. With such questionable objects of study (far removed from the paradigms of the natural sciences), no wonder incantations about methodology are wheeled in to cover the epistemological incoherence. And to study media without recognizing the mediated nature of the inquiry and its objects of study is circular.

Two questions follow. The first is how might we avoid the potentially vicious circularity which besets human scientific inquiry, about which scholars 
as different as Foucault (1970) and Habermas (1987) concur? Reflexivity has its limits, because the criteria of judgement are themselves wrapped up in the 'methodology'. The notion of critical, or ethnographic, understanding offers one possible way forward. The second issue, which will occupy much of this piece, is the relevance of a missing object of study commentary.

Ethnography by participant-observation is often trumpeted as anthropology's main contribution to the human sciences. Considered as a practice, it is obvious though that, however brilliant and deep the insights, ethnography is inevitably something of a glorious muddle, not some methodological solution. The value of ethnography is, I suggest, quite different. Growing out of the long-term implication in some other people's ways of living, it lies in the ethnographer's recognition that she is positioned between two partly incommensurable discourses - the analyst's world as academic and cultural subject, and the understandings, arguments and working presuppositions of the subjects of study - between which no resolution or synthesis is possible. ${ }^{3}$ The lack of synthesis however makes for critical distance and inhibits circularity.

Ethnographic understanding involves appreciating how people judge and comment on their own practices, while simultaneously analyzing the circumstances under which such practices occur, employing current academic criteria. This understanding is critical in the strong sense that is not only critical of the object of study, but of the practices and categories of the knowing subject, the analyst's own. It is in this encounter that the ethnographer is confronted by the Eurocentrism of her own thinking and presuppositions. It follows that, if research is not simply to reiterate hegemony, such cultural translation must be dialogic, again in the strong sense that academic presuppositions and practice themselves are continually called into question and interrogated through the dialogue.

The relevance to Asian scholars and media practitioners should be obvious. With the growth of both media industries and media studies across much of Asia, the phase of acquiescing to Euro-American hegemony requires questioning, if Asians are to appreciate the richness and diversity of media practices and production across the continent and allow these to inform their critical thinking. ${ }^{4}$ More specifically, for Indonesians the way that mass communications naturalized a narrow vision of development and the polity makes critical engagement with both the media industries and communications

3 Such cultural translation applies as much to contemporary media industries as to the remote tribal peoples, with which the discipline is associated. The point of Kuhn's The structure of scientific revolutions was that even natural scientists have their own social communities of practice which are not simply reducible to the canons of rationality, but are inherently cultural.

4 The narrowness of mass communications is evident in the failure to recognize 
studies vital if the reform process is to be anything more than empty gesticulation.

Even allowing for recognition of media-related practice and the implication of people as subjects in the mass media, how can the opinions of a handful of Indonesian villagers matter? What after all, have they to say that could possibly be relevant on such a lofty topic? What I hope to show here is that what ordinary viewers have to say requires us to rethink the object of study in communication and media research, and so what we are doing in fundamental ways.

Such rethinking is, I would argue, overdue. The question is why have so few people challenged existing approaches over their manifest Eurocentrism? Unfortunately most scholars are too deeply invested in the status quo to wish to cut their own throats. And the studies which claim to make a break from this intellectual hegemony (e.g. Shohat \& Stam 1994; Curran \& Park 2000; Erni \& Chua 2005) all too often end up, ironically, to paraphrase one title 're-westernizing media studies'. The reasons are simple. Insofar as what is at issue is only the immediate object of study imagined unproblematically as non-Western or Asian media, the theoretical frameworks and goals remain unquestioned. Recognizing how hegemonic the epistemological practices of media studies in fact are falters at the next step, namely how to step outside this seemingly all-embracing discourse.

Even were it desirable, is it possible to avoid Eurocentrism? After all, are the modes of inquiry and the academic institutions themselves not inescapably 'Western'? Implicit in such arguments is an elitism which privileges expert and scholarly knowledge and finds it hard, as the old actor above remarked, to listen to anyone else. A myopic narcissism is at work, which ignores quite how much and how varied what is going on is. For instance, immediately, there is a long history of discussion, argument and reflection about Asian media, not least by the media themselves - what I call 'intermedia' commentary. ${ }^{5}$ To dismiss the working practices of those who are 'organically' engaged (Gramsci 1971), whether as producers, audiences or critics is not just bad manners, it alienates people from their own thinking.

historical diversity and cultural context. It parallels facile essentializing about Asian media and even 'Asian values' (see Chua, B-H 1995) as if there were some natural, timeless entity called Asia.

${ }^{5}$ Many of the ideas about how radically to rethink media and film studies, including the relevance of intermedia commentary, have been worked out over the years with my colleague, Ron Inden. 


\section{Media versus Communications studies}

How might differences between communications and media studies bear on the kinds of issues outlined above? What do these differences actually boil down to in different regions of Asia in the twenty-first century? What happens if, instead of attempting to explain everything using the old, formal dichotomy of theory and methodology, we inquire about differences in intellectual practices and their genealogies?

For a start, is it possible to rethink the relationship between naturalist or substantialist and critical-cultural schools of thought, without having to dismiss one as trivial or unimportant? ${ }^{6}$ What if they are different phases of inquiry? The Oxford philosopher, R.G. Collingwood, argued that empirical and philosophical modes of inquiry are distinct. If you are researching, say, television-viewing or the ownership of mobile phones, it makes sense in the first instance to assume you can work with, and allocate evidence into, distinct classes (what constitutes ownership, viewing, social class, occupation, etc.). In short, when you begin to inquire about a phenomenon, you assume that it is approachable in terms of discrete and unambiguous categories. You do not worry too much at that stage how epistemologically or ontologically justified they are, whether they are a combination of popular and scholarly ideas, or how much they are themselves mediated.

When you have reasonably established what sort of phenomena you are dealing with, a different phase of inquiry begins, in which you start to reflect on what it is you have established. This latter, Collingwood called the 'philosophical' phase of concepts, where categories overlap and do not permit closure. The question then becomes: what significance do the findings have for our broader understanding (1933: 21-53)? At this stage new questions arise, such as what are the practices which underpin industrial processes of production or how do broad statistical trends in viewing relate to individuals and the circumstances of their viewing? Such critical reflection may well lead to asking new questions and so a new phase of empirical inquiry. Is this distinction a useful way to consider differences between naturalist and critical cultural schools of thought?

Rephrasing the difference between schools as one of practices of inquiry raises the question of what are the implications of adopting one approach rather than another. The differences are at once theoretical and practical. In other words, they are what Ernesto Laclau and Chantal Mouffe called 'antagonistic' (1985: 91-148). Apart from antagonisms arising from differences

6 The kind of realism and pseudo-empiricism widely found in mass communication studies is a version of philosophical substantialism; see Collingwood 1946: $41-45$. 
of class and relations of production, other modes of differentiating humans as subjects become pertinent, be they relations of gender, ethnicity, sexual orientation, age, differential positioning with access to knowledge or whatever. On this account, by its nature, society does not submit to a single explanation, because it is neither a total, nor a coherent, entity (Laclau 1990a.). Insofar as media and communication are social activities, the same holds for them. There are always antagonistic explanations of society and social action. So,

antagonism as the negation of a given order is, quite simply, the limit of that order, and not the moment of a broader totality in relation to which the two poles of the antagonism would constitute differential - i.e. objective - partial instances (Laclau \& Mouffe 1985: 126).

In reflecting on differences between communications' and media studies, we shall have to consider the limits of each in understanding mass media in contemporary Pacific Asia.

On my understanding of Laclau and Mouffe, the antagonisms of analytical interest may or may not be manifest in explicit conflict. While the New Order strongly discouraged media coverage of a range of sensitive topics, notably those dealing with ethnicity, religion, race and interest group or class, ${ }^{7}$ this simultaneous substantialization and avoidance tends to distract attention from the constitutive antagonisms. Once recognized, it becomes evident that these were, and are, played out every day right across the mass media. For example, the contradictions and incoherencies of masculine authority and power are displaced onto women, whether, for instance, as dangerously independent career women or cruel step-mothers and mothers-in-law in Indonesian soap operas, or the staple figure of the womanas-suffering in cinema. ${ }^{8}$ Equally striking is the portrayal in television of working class people as ugly, ill-educated, stupid, instinctual, clumsy and often comical. ${ }^{9}$ The denials and disarticulation involved are remarkable for being so un-remarked on.

7 Media coverage of 'a range of topics are widely recognised as off limits, and have been dubbed with the mnemonic "miss sara" which refers to anything deemed seditious, insinuating, sensational, speculative, or likely to antagonise ethnic, religious, racial or "group" (class) tensions' (Hill 1994: 45), cited in Fox n.d.

${ }^{8}$ As elsewhere, much concern is invested in the sexuality of women. For film Sen (1982) addresses the way women are portrayed as dependent and sinful, while Heider (1991) notes how social and domestic conflicts are resolved through the physical or emotional suffering of the women involved.

9 The exception is the series SiDoel Anak Sekolahan, Si Doel the educated. Derived from a popular film, the hero, played by the original boy actor makes it through the educational system, but decides to quit, to drive a jitney bus and return home, where he is surrounded by the usual caricatures of the Indonesian poor. That this 
Other aspects of the cultural difficulties in recognizing issues of class and power are evident to ordinary viewers like the Balinese villagers mentioned earlier, if not to the media producers. Let us consider the main ways in which the polity and models of political relations have been represented on television since the 1990s. Briefly we can broadly distinguish two kinds of representations. The first is a hierarchical model of social and cosmic division of labour in which different kinds of beings have exclusive functions and where power is distributed in complex, often non-manifest ways. ${ }^{10}$ The second is what, for lack of a better expression, I shall call democratic capitalist models, different interpretations of which underpin the conflict between New Order, secular reformist and moderate Islamist visions.

These two pairs of paradigms are not simply related as 'traditional' and 'modern' models, as both have long been invoked in Indonesian political discourse. What each involves depends on who is representing it, as what, under what circumstances - which is where the mass media come in. Antagonisms arise in at least two different ways. First, in social life humans as social agents are caught up in complex and untidy relationships, which are not reducible simply to neat logical structures of classes, roles etc. Second, even in the classic case of a worker selling his labour in the market, that does not in itself make the capitalist relationships of production intrinsically antagonistic (Laclau 1990b: 9). Extrinsic factors, such as a fall in the standard of living in the model of capital or the manifest abuse of reciprocal obligations according to the social and cosmic order, bring about antagonisms. ${ }^{11}$ The latter point was clearly stated by the Balinese commentators. The glaring disparities of wealth and life choices that daily confront Indonesian television viewers expose the limits of both orders.

series consistently scored top ratings, yet none of the television companies got the point and decided to portray the struggles of able working class people is telling.

${ }^{10}$ Sometimes this differential order is summed up as $(H) a d a t$, on which the classical reference is Schärer (1963). Since the end of the New Order, magazines and television programmes devoted to 'mysticism' have burgeoned. Dismissed by secular rationalist and Islamists alike as dangerous and reactionary, I would argue that these are popular ways of questioning the dominant political and religious movements which continue to disarticulate ordinary Indonesians by referring to alternative ways of understanding power and human motivation.

11 There is therefore always a constitutive outside inherent in any antagonistic relationship (Laclau 1990a: 9). The notion of a constitutive outside, which Laclau derives from Henry Staten's (1986) reading of Derrida, turns out to be a flexible and powerful means of analyzing antagonisms, which are sutured over, notably in the mass media. 
This brings us finally to the issue of that much over-used term, hegemony. On this account hegemony rests upon antagonism. It is how the imbalance between the poles of an antagonism is articulated at any moment.

Hegemony supposes the incomplete and open character of the social, that it can take place only in a field dominated by articulatory practices. This, however, immediately poses the problem: who is the articulating subject? (Laclau \& Mouffe 1985: 134).

So the social is the product of articulatory practices, notably by the media. Several questions then arise. Who, or what, are the agents, instruments and patients (recipients) of these hegemonic articulations? How would we set about studying them? What is the role of academics in researching and writing about, and so articulating these articulatory practices? And how do the kinds of articulation communications studies' scholars make differ from those of media studies' scholars? And, finally, what is the relationship of academics to the articulating subjects and to the objects of articulation?

\section{Practice versus structure}

Few terms have been used as indiscriminately in the human sciences in recent years as practice. The phrase 'media practices' falls easily off the lips, but what exactly do those who use it mean by it? In the absence of a coherent account of practice as an ontological object, it seems to connote little more than disaffection with the formalist vocabulary of structure and process, with perhaps a frisson of political radicalism by association with the almost equally problematic Marxist notion of praxis. A workable account of practice however might bridge some differences between substantialist and critical approaches to media. Practice invites empirical research, but extends to include the intellectual practices of the researchers, so making the study critical, in the strong sense above of being reflexively critical of both the researcher's practices and presuppositions. The scope for historical and ethnographic study into media-related practices is vast and still largely uncharted. No theoretical notion is unproblematic: the shortcomings of 'practice' as a notion will no doubt emerge as critical research gets under way.

Are existing theories of practice not adequate? What, for instance, of the work of Pierre Bourdieu? As Richard Jenkins argues (1992), Bourdieu never addressed the radical ontological or epistemological problems, which a more rigorous account of practice would require. Instead he used practice to supplement the inadequacies of structure, as a prop to compensate for the more glaring inadequacies of notions of system and structure. Bourdieu retained a surprisingly conservative ontology. Consider, for instance, what is presupposed in the idea of symbolic capital (a hybrid of a Romantic 
theory of the sign coupled with a deeply contested nineteenth century notion) or the dichotomy implicit in a 'theory of practice', 1977.) We have to turn to the work of Foucault to find a serious analysis of practice, with an appreciation of the radicality demanded by philosophical pragmatism, in which the pseudo-naturalist neutrality of the scholar as knowing subject is clearly revealed as an inextricable part of the problem. ${ }^{12} \mathrm{I}$ take Foucault's shift from an archaeological to a genealogical method to be such an attempt (e.g. 1977b). Foucault was particularly interested in the different modes by which human beings are made subjects and are transformed - or transform themselves - through their knowing practices (1982: 208). The media, I suggest, are such a mode. And they involve two related sets of practices: those by which people change themselves or are changed; and those by which they become objectivized through their implication, or engagement, in the media.

Rather than talk of 'media practices' however, I prefer the expression 'media-related practices'. It may be the residual anthropologist in me, but it is the range of contexts and situations in which media become relevant, which seem as interesting as what goes on in the media themselves. Anyway it is hard to determine where you would draw the boundary. If housewives cook to have meals ready for the family to watch television, or families save up to buy a new set, media conglomerates deciding strategies to increase market share or what politicians say - and more importantly do not say - seems to me at least as interesting as media practices more narrowly defined. ${ }^{13}$ On this account media-related practices do not form a closed field: they are incomplete and open.

How does a concern with practice differ from other ways of conceiving of the object of media studies? It is an attempt to break away from

12 Theory does not express, translate, or serve to apply practice: it is practice. But it is local and regional ... not totalizing. This is a struggle against power, a struggle aimed at revealing and undermining power where it is most invisible and insidious. It is not to 'awaken consciousness' that we struggle (the masses have been aware for some time that consciousness is a form of knowledge; and consciousness as the basis of subjectivity is a prerogative of the bourgeoisie), but to sap power, to take power; it is an activity conducted alongside those who struggle for power, and not their illumination from a safe distance. A 'theory' is the regional system of this struggle (Foucault 1977a: 208).

Foucault was then clear that an analysis based on practice upset the cosy relationship of intellectuals with their object of study, the implications of which communication and media studies needs urgently to take account.

13 I take practice to be a recognized set of actions which affects the world or agents, or commonly both in differing degree and kind. Activities I consider to be congeries of actions in which people engage either less formally or where not much is changed by doing so. Sitting university finals exams and going fishing are examples of a practice and an activity respectively. As we shall see, under what circum- 
a long-standing explanatory dichotomy between structure on the one hand and individual agency on the other (replicated, for example, in Giddens's theory of structuration, 1984), as if these were the only alternatives. Instead of the object of inquiry being timeless and unsituated, the shift in emphasis is to more historical and anthropological concerns, perhaps crudely summed up in such questions as: 'What happened, and what was presupposed, on particular occasions?' 'Who represented this as being what, to whom, and under what circumstances?'14 Applied to media, the second pair of questions is significant because, on most interpretations, they involve communication and mediation and so take us to issues of the media on the media - or 'intermedia'. Inquiry into practice then assumes some kind of prior inquiry into how mass media are conceived and organized, which mass communications is designed to address. However recourse to ideas of practice is not simply another stage of inquiry, because in many senses it marks a rupture. Theoretically, any serious recourse to practice questions the presuppositions of preceding approaches. In the stronger versions, such rethinking is often designated as 'post-structuralist'. ${ }^{15}$

As the term suggests, such an approach aims to go beyond ideas of structure and its associated concepts, whether formal, such as system; or distributional, as in (social) organization; or supplementary, as are ideas of process. Socially, structure is not a natural fact. When we describe the media in terms of institutions or legal corporations, we are invoking a culturally and historically specific genealogy of argument. Similarly, if we are studying, say, patterns of cinema-going in India or sampling responses to television programmes in Singapore, as Ian Hacking pointed out (1990), we are invoking a kind of fact invented in mid nineteenth-century Europe: the statistical fact or the 'normal'. If we are considering the impact of entertainment media on audiences, then we are assuming some account of agency.

In media and cultural studies, structure stands in an ambivalent relationship to culture, the semiotic, or meaning. At one extreme, structure (often linked in some way with the 'hard', masculine realities of economics and politics) determines, or at least is a good way of explaining, culture (as 'soft', malleable, feminine). At another, culture is the domain of human imagination, through which humans free themselves from, and come to understand the workings of, structure itself. More radically, structure stands

stances commentary is a practice as against an activity, may be crucial. My usage is consonant with the main senses of practice in the Oxford English Dictionary.

14 'Who' here questions the kind of agent, which may well not be an individual person, but a complex and changing grouping (Hobart 1990)

${ }^{15}$ I carefully avoid describing such critical thinking as 'postmodernist', for reasons outlined, for instance, by Baudrillard (1993). 
in opposition to contingency, to the questioning of the predictability or explicability in the last resort, of what happens (Laclau 1990b). It is the activity of the knowing subject upon the world, which creates, or reveals, that structure. So recourse to structure opposes the knower to the known. The sort of analysis of practice I am advocating takes issue with all these assumptions.

Some brief examples from cultural studies may make the point. A feature of the work of the Birmingham Centre for Contemporary Cultural Studies was the extent to which it enshrined and played with, rather than transcended, the dichotomy between cultural voluntarism and structural determination (exemplified in Hall 1980). As Chen has pointed out, Cultural Studies has notably failed to address the potentially radical dissolution of its constitutive categories by post-structuralism (1996).

The problems surface in a well known critique of popular culture and cultural populism, McGuigan complains of Fiske's work on television (1987), that he

says next to nothing about institutional change in television during the 1980s: vital issues to do with de-regulation / re-regulation and technology, for instance, are simply banished since, for Fiske, they are not pertinent to questions of interpretation ...

Following Bourdieu, Fiske separates 'the cultural economy' (symbolic exchange between texts and audiences) from 'the financial economy' (where the television industry is located). Fiske believes it is completely unnecessary to interpret the meaning of the former in relation to the commercial operations of the latter...

A satisfactory theory of television, I would suggest, needs to account for the multi-dimensional interaction of production and consumption at both economic and symbolic levels, giving due weight to textual diversity and audience differences, as Fiske rights recommends (McGuigan 1992: 71-72).

The trouble is that McGuigan, in a blast from the past, reinscribes the dichotomy for which he attacks Fiske and cheerfully reifies the economic, symbolic, production, consumption, audiences and so on. Although McGuigan might seem here to give equal weight to the economic and symbolic, the point of the book is to remind readers just how far popular culture is in the grip of powerful and determining economic structures. In practice however, commercial interests cannot simply be separated from 'content'. And what exactly are scholars doing when they dichotomize the economic and semantic? For all their claim to radicalism, most of the protagonists in the debates around cultural studies seem firmly entrenched in the metaphysics of a Eurocentric modernism.

Am, I not just reifying practice in a new set of objects, such as 'commentary'? I think not. In some ways, what I mean by commentary is close to the French discours, the open and unbounded discussion that is part of 
almost any social activity or practice, which became substantialized as 'discourse' in English-speaking translations. An interesting aspect of recent work on audiences is precisely that it does not attempt to essentialize the audience as a natural object. Instead it considers those practices of media institutions, governments, academics and others, through which they describe, survey and imagine in different ways audiences as different kinds of entities (e.g. Ang 1991, 1996; Hartley 1992, 1999; Morley 1992; for Indonesia, see Kitley 1998). Equally there are problems in essentializing differences between producers, distributors and audiences into bounded compartments. Producers regularly meet as audiences to view and judge their own and competitors' productions.

\section{The claims of commentary}

Rethinking the object of media studies as those practices which go on in and around the mass media suddenly makes it clear how little we know and how much we still have to investigate. Practice is often invoked as a way, as Ien Ang put it, of 'desperately seeking the audience'. While it is the complexities of researching audiences which has attracted the most attention, ethnographic studies of how different kinds of media production or distribution actually work, as opposed to how they are supposed to work, are proving just as informative and surprising. The research of students of mine, who are investigating media production in industries as diverse as magazines, television and news production from Jamaica and Kenya to India and Singapore, beautifully illuminates that how producers actually work is as exotic, unexpected and interesting as any classic ethnographic study. Because we have been so focused on the media as structures and organizations, we have as yet little idea what practices may prove significant.

Among the many practices which make up contemporary mass media, some are reflexive. That is they are about the practices themselves. Just as a crucial, indeed constitutive, set of media practices frame, represent, modify and articulate events, actions, texts or what have you, these practices comment on and articulate these articulatory practices. In this sense they are meta-practices, meaning not of some higher order, but simply ones that come after. I shall use 'commentary' here as a way in singling out those kinds of practice, the constitutive purpose of which is to comment on previous practices of articulation. Representation and commentary both supplement and modify what they refer to, but to some extent in different ways. As Goodman noted, representing works by eliminating most information and by transforming what remains (1968). A picture represents something as something else. Commentary expands on or modifies such representations. 
Why should this framing and reframing be necessary at all? I take it, following Quine (1953, 1960), that events and actions are underdetermined. That is, for any set of facts, there are a variety of ways you can explain, interpret or understand what is going on, each of which make sense of those facts, even if in different and incompatible ways. One of the more unnerving experiences of fieldwork by participant-observation is that when you have observed something important, you have to rush up and ask what you have just witnessed is actually about. Events do not explain themselves. The kinds of closure, well described in studies of television production (e.g. Fiske 1987), perhaps especially for the news (Fiske \& Hartley 1978), are ways of determining, what is otherwise non-decidable. Even news stories, arguably among the most highly structured of genres, leave themselves open to all sorts of possible interpretations. Commentaries often work to restrict the possibility of dissemination. One way they do so is by telling you the context or the situation, which is relevant to appreciate the facts, tell you what sort of facts they are, the kind and degree of reliance and the kind of understanding - in other words, how to understand them.

Commentaries do not necessarily over-determine, but may do the opposite. Confronted with a definite-looking fact, a commentator may show that things are not what they seem. The trouble with determinations is that those who enunciate often do not manage to agree among themselves.

Is it possible to devise a classification of kinds of commentary, whether of Asian media or of media in general? Such an exercise runs the risk of hypostatizing what are analytical and situational distinctions. Whether some statement or act is commentative depends on the circumstances of its utterance, for whom it is intended and how it is understood. Something similar holds for media 'texts' more generally. Even Stuart Hall's argument that it is possible to distinguish 'dominant-hegemonic', 'negotiated' and 'oppositional' readings of media messages (1980b) presupposes a thoroughgoing essentialism (Hobart 2005). Anyway, not only are there presumably as many ways of commenting as there are 'illocutionary functions' (in Searle's 1971 sense), but presumably commentaries arguably may be considered to have multiple functions. Commentary is best left as an analytical notion.

Re-appraising existing work in terms of commentary already suggests new possibilities. What are asking viewers their thoughts on Dallas, or conducting questionnaire surveys about Singaporean TV, if not highly structured invitations to comment? And what are trade journals doing if they are not adding authoritative or insiders' commentary? If you stop and think about it, one of the main activities of the mass media is commenting on their own productions and those of other media. The variety is surprising. It ranges from the obvious to the less expected. It would include newspaper 
reviews of films and television programmes, the writings of media correspondents, trailers and promotions, trade and in-house journals and fanzines, films and television programmes about making films and broadcasts, web sites for computer and media fans, blogs, chatting about last night's soap round the coffee machine and much else besides.

Commentaries are remarkably pervasive. But what we actually know is less the product of carefully tailored footage of images and voices than of commentaries. No day goes past without politicians, generals and 'experts' telling us what is really happening. As we know from the Gulf War and subsequent wars, what we see on our television screens is not what took place. As Baudrillard noted (1995), images are selected to confer actuality and authenticity upon the commentaries. ${ }^{16}$ The point also emerges from Fiske and Hartley's notion of claw-back in news (1978: 81-87), by which eye-witnesses' and on-the-spot reporters' accounts are subordinate to, and structured by, the studio presenter's commentary. One person's fact is someone-more-powerful's commentary. So is it surprising that, when events are imagined to matter, political commentators - for whom, significantly, we use the term 'pundits' — hurl themselves into the breach with a selfsacrificing devotion worthy of Orientalist imaginings of the Juggernaut?

Who then is empowered to comment, about what and under what circumstances? What the village commentators had to say was marginal to much of communications and media studies, not because of what they said (that - later - excited the publishers), but because of who they were or, rather, were not. Had they been recognized political commentators (who, under the New Order, were notably quiet), they would probably have been hailed for their perspicacity. So what is informed commentary and what mere opinion, idle speculation or empty chatter would seem to depend on who says it. No prizes for guessing who usually gets left out.

A point of some significance is that an analysis in terms of practice may fit at least some strands of South Asian philosophical thinking rather better than the present options. Certainly critical thinking about, and use of, commentary is highly developed. Indian philosophical thinking about the nature of language, as exemplified in grammar, translation and commentary, recognizes, as does Balinese, that translation presupposes some original to be 'faithful' to, which is almost by definition absent. What is most significant though is the idea of after-speech, Anuvada, which involves a dialogue with some prior text. So elucidation or commentary, vyakarana (kawi: wyakarana) supplements and becomes part of the text-as-a-whole. ${ }^{17}$ Far from there being some timeless, generic 'Asian' mode of thought into

16 Baudrillard's argument in The precession of simulacra is about questioning what determines the relationship between image and reality (1983: 11).

${ }^{17}$ I am indebted to an essay, which I unfortunately no longer have, by Adiya Dev Sood, a student of Ron Inden, which provides an elegant analysis of how we 
which we can tap, there seem to have been a host of historically distinct and indeed rival discours, ranging from the great written philosophical texts to popular understandings, which are equally coherent nonetheless. By concentrating on American and Europe academic thinking, Asian scholars may be missing extraordinarily rich and diverse discours in their own various backyards.

Let me now turn to how different kinds of media address themselves to recipients, how they imagine and situate themselves as producers and the kinds of commentary in which they are engaged. All the materials cited are about Indonesian television.

\section{The limits of commentary}

Many kinds of commentary are too obvious for me to dwell on at length. Examples are popular political commentary in the form of graffiti, pop songs, jokes, rumour, nicknames and a myriad of other forms, which abound even under conditions of fairly rigorous censorship. Another is the role of retail magazines, which preview and review films and television programmes, and frame production and personnel. Film magazines, whether for fans or the general public, have been much more studied than television magazines. For example, for three years before it ceased publication in the summer of 1997, Vista-TV, a fortnightly up-market Indonesian consumer magazine extended itself way beyond reviews of programmes to offer a comprehensive critique of state television as 'the propaganda arm' of the Suharto government and 'freedom', which in this instance meant commercial competition. Indeed inter-media argument conspicuously includes attempts by the print media to claw back the enunciative function from television (film may try something similar, Stokes 2000). There has been a long running debate in the Indonesian broadsheets about the pernicious 'influence' of television upon the masses (Hobart forthcoming). Such commentaries presuppose that the facts are not strong enough to speak for themselves, but require further articulation. Attempts to determine how readers and audiences are supposed to understand the mass media is only a small aspect of a more complex process. To a greater or lesser degree any articulation forecloses the range of possible responses and disarticulates alternatives. Commentary may silence as much as it explicates.

\section{Excoriating corruption and staying alive}

In Indonesia theatre has conventionally been a means to social criticism. Even under conditions of harsh repression, mutual knowledge of rhetorical

would have to rethink our assumptions about language use were we to take Indian writings on language philosophy seriously. 
forms enabled audiences to understand what actors were implying without anything explicit being said. Such theatre often resembles a form of guerrilla warfare: the actors have packed up and disappeared, leaving only traces in the memories of audiences. When such theatre is televised and so recorded, the stakes are raised.

In the summer of 1991, in Bali everyone I knew was talking about a theatre piece held as part of the annual International Bali Arts Festival and broadcast on the regional channel of state television. The play was a Séndratari, a 'ballet' spectacular, performed by a large cast, with an orchestra and ranks of singers, a theatre form identifiable with the New Order (Hough 1992). The plot drew on a classical episode in the Mahabharata, the 'Pandawa Asrama', when the five Pandawa brothers are forced into exile in the forest. All the narration and dancers' voices were articulated by a single dalang, or narrator or puppeteer, from one of the two main performing arts' academies, KOKAR (Konservatori Karawitan Indonesia, the Indonesian Conservatory of Music). The dalang, Déwa Madé Sayang, was not only a superb performer, but also a trenchant critic of abuses by those in high places. What excited those I spoke to was that he had excoriated some of the most senior figures in Indonesia in front of television cameras, with two of his targets in the large festival audience.

In the story, before the Pandawa brothers are exiled, they meet the sage Bagawan Biasa, who advises them how to be good rulers and warns them of the grave consequences for them and their subjects of doing otherwise. In 1991, when Déwa Madé Sayang performed this piece, commentary on corruption and abuses of position by the President, his family and government officials was still relatively muted, although widely rumoured, despite tight media censorship.

What Bagawan Biasa said was:

If you are the leader of a people, if you rule over them, you cannot live too well. You must not have too luxurious a life-style, but should live simply. You are such a leader. Now none of your subjects should be allowed to be corrupt - that is what you must command. But this must be seriously observed in practice. It should not just take the form of words: you order the masses to obey, but then it turns out that you did not do so yourself. That is the difficulty of becoming a ruler. It is easy to give orders; it is hard to put them into practice. That is the first thing to grasp.

When a ruler is not honest, the world goes to rot. No way may you do that. This is what it is to be just. You have to strive to be fair and just to all of your subjects. On what do you base fairness? On the Four Kinds of Circumspection: Even-handedness (Sama), Discrimination (Béda), Generosity (Dana) and Strictness (Danda). Even-handedness: you should give to your subjects equally. The Kingdom of Indraprasta flourishes - who is responsible? All the subjects, all the officials, are the reason. All the armed forces are the 
reason. Because the ruler treated them all equally. If people should perhaps struggle to make a living, give those more - that's called Sama.

He then turned to the arts and urged good leaders not to favour one group of artists over another. Otherwise those neglected will be angry; gossip will start and the ruler will be discredited. He then remarked that generosity and punishment should be judged by worth, not by family or favour.

Those I asked agreed that the dalang's intended targets were President Suharto and his family, and also the then Governor of Bali, Ida Bagus Oka, who was widely considered to be very corrupt and to have authorized tourist development that was very destructive of the island as a whole. The final target was Professor Madé Bandem, the director of the rival arts' academy (STSI, Sekolah Seni Tari Indonesia, the Indonesian Academy of Performing Arts) whom the dalang held accountable for hogging invitations for overseas tours.

The dalang placed himself here in a complex relationship with his audience. He spoke with great enunciative power: with the authority of having mastered the texts, of being qualified to judge their relevance to a broad range of circumstances. It was the blast of a modern - but also traditional - intellectual, who took his lords and masters, the intellectuals who did their bidding and those in opposition who chose to stay quiet, to task for abject failure. Although the speech was understood as a searing commentary on the régime, nationally and locally, Déwa Madé Sayang carefully adhered to the proprieties of commentary on rulership in ancient India or Bali. At once he condemned a paternalistic corrupt régime, yet deferred to the audience as to how they chose to interpret his words. ${ }^{18}$

I trust it is clear by now why I am reluctant to classify kinds of commentary - or indeed what is commentary - because in theatre what is text and what commentary is ambiguous. By contrast to Euro-American conventions, where the author or performer to assumed to be the agent, Javanese and Balinese appreciate the central role of audiences. While actors and puppeteers often draw more or less implicit comparisons between situations, problems, moral dilemmas and so forth in performance and bring about the juxtaposition, it is members of audiences who draw their own inferences. The commentary is the more elegant and effective for being implicit, because each person can decide how it applies according to their own circumstances.

${ }_{18}$ I am not guessing on these points. In discussions, Déwa Madé Sayang was quite explicit about the dangerous task that had been placed on the shoulders of actors, by the failure of other intellectuals and media figures to stand up to tyranny. He was also clear that it was up to individual members of the audience to understand the characters' words as they saw fit. 
But is this commentary? Everyone I spoke to considered it to be. Some drew my attention to an aspect I had overlooked. The speech was not simply a complaint, a public voicing. It was targeted at officials who were corrupt, had favoured their families and friends, who had failed to be just. The expression used was negakin debong, to sit on a wet banana stem: the moisture slowly seeps through your clothes until you suddenly realize you are very wet. Any official who retained some vestige of humanity, on hearing this speech would be forced to reflect on their actions. According to Balinese ideas about meaning (Hobart 1999b), unless a statement has a discernible effect, nothing has happened: it has no meaning. Whether what the dalang said is commentary or not depends therefore on whether people paid attention and appreciated it. It is audiences who determine what is commentary.

We seem to have reached a limiting possibility. Commentary cannot be singled out as a discriminable class of phenomena - indeed its efficacy in the example above lies both in it not seeming to be so and being open to how different people may, or may not, choose to relate to it. Whether something is, or is not, commentary turns out to depend upon the occasion, the particular circumstances and the relationship between the speaker and different members of the audience. How come this has not been more obvious? It is, I suggest, because of the pervasive substantialism that permeates communications studies, which leads to serious difficulty in appreciating that we are dealing with ways of relating things (practices). Indeed the objects themselves are relational, as the verb 'to mediate' suggests. Media are directed to something beyond themselves, ${ }^{19}$ to the extent that their objects are not simulacra (which merely makes things worse, Baudrillard 1983).

Why then should there be such a bias towards closure around the circumstances of production, whether imagined as political-economic determination of content, ideology, a reified 'text' or 'encoding' of messages? The short, if not pleasant, answer is that it makes life immeasurably more comfortable for scholars. It shores up the cosy myth of the shared superiority of producers and academic commentators. Ignoring the extent to which mediation is relational and situational allows academics either to dispense with the awkward contingencies of production and reception or

19 The philosophical approach here is pragmatist, as C.S. Peirce's analysis of relations of relations makes clear. Actions and practice are directed. That is they are directed towards bringing about a state of affairs, which is not already, or entirely, the case. They are directed to an end outside themselves and so are contingent. The media appear to be the opposite, in that they mediate pre-existing entities. A moment's reflection suggests though that mediation transforms what it mediates and so is one kind of practice. 
to imagine themselves as knowing subjects sufficiently universal as to be able in principle to occupy all relevant positions of producers and audiences anywhere. To the extent that mass communications scholars are functionaries of government and media corporations, this makes a certain sense. To the extent they claim to be independent, libertarian or radical, they are fooling no one but themselves.

If the study of mass media is complicated, untidy, partly contingent and partly unknowable, it is not much of an excuse for intellectual myopia and recidivism. That existing approaches are inadequate is not a reason for not rethinking what we do. I think it was J.K. Galbraith who once remarked that, faced with the overwhelming case for changing your mind and thinking of reasons not to, most people immediately start thinking up good reasons.

\section{Just when you thought it was safe to come out}

If explanatory closure around production and its objects is inadequate, is the study of reception the answer? As a comprehensive alternative, the answer is evidently 'no', because it commits an equal and opposite substantialization. Also reception is the subordinate term in a trichotomy of production: distribution: reception. The problems of addressing reception are evident when you consider how pervasive the metaphor or synecdoche of 'consumption' of mass media has become..$^{20}$ Because mass media are inter alia businesses, it does not follow that every aspect of it can be explained as a business. Or, because for expository purposes it may be helpful to imagine, say, making and appreciating television programmes as a process of production and consumption does not mean that it is, any more than because it may be illuminating to treat culture as a text; culture therefore is a text.

One reason for proposing media-related practices as the object of study is precisely to break away from the closure which results from imposing models on complex and underdetermined actions. I therefore refer to such practices as a congeries, because they do not, on this account, form a system, but are situated, open-ended, labile and changing.

\section{The Governor of Bali awards the prizes}

My second example is the lead news item from Balivision, a daily Englishlanguage broadcast in April 1997 by state television in Bali, aimed primarily

20 The opposition of mass culture and high art sneaks in here. We are happy to talk about consuming television, game shows or whatever, but to say you went to the theatre to consume King Lear or the Ramayana sounds odd. 
at tourists but, for intriguing reasons, with a large Balinese following. The piece was about the Governor of Bali presiding over the annual competition to judge the best 'Traditional Village' (the translation of désa adat, itself a hybrid term of Dutch colonial ancestry). As was standard for state television, even the Governor did not speak for himself but, just as the dalang spoke for the entire cast of the Mahabharata, the event relied on voiceover. Here commentary supplanted the original text entirely. As with most scenes of government VIPs, the camera followed the movements of the Governor and his entourage as he met (less) important people against a backdrop of the well-behaved masses, who exemplified Foucault's 'docile bodies' (1977c).

The commentary was in factual but momentous tone, with the familiar tableau vivant presentation that Kitley has noted attended New Order ceremonies (1998). There were extensive details of places and people's names (where the ceremony happened, which villages and actors won), that would have been completely meaningless to the intended audience, as would the extended reference to a recondite religious categorization..$^{21}$ Commentary can articulate black as white and square circles. The Governor's expressed concern about protecting Bali from the ravages of tourism needs to be set against television news footage after Suharto's resignation, when demonstrating university students singled out the Governor as the figure primarily responsible for the damage.

It is the final line, however, which interests me as it sounds like a direct quote: 'Participants who did not win this time should try to increase their development and capabilities'. This is probably not an infelicity in

21 The voiceover read:

Yesterday Bali Governor Ida Bagus Oka presented an award to the winner of the Traditional Bali Competition for 1991-1997 at Wantilan Taman Ayun, Badung. First place went to the Mengwi Traditional Village, sub-district of Mengwi, Badung Regency. They received an award and cash totalling Rp. 4,500,000. In second place was Tegallinggah Traditional Village at Bedaulu, Gianyar and third place was taken by Betanja, sub-district of South Denpasar.

The Wayang-Arja Parade Competition was also held. First place went to I Nyoman Sudana, a puppeteer from Badung Regency; second to I Wayan Karsa from Bangli; and third place to Déwa Putu Banjar from Gianyar Regency. The Governor said that we have to protect the negative impact of tourism by maintaing our customs through Traditional Villages and the Tri Hita Karana concepts, which include pahyangan, pawongan and paumahan. He added that participants who did not win this time should try to increase their development and capabilities.

Briefly, the Tri Hita Karana comprises the three elements of Divinity as allpervasive, which make possible the emergence of good in this world, in spirit, thought and body. This was one of many formalizations necessary for Balinese to meet the criteria for an accepted religion under the New Order. 
translation. ${ }^{22}$ A central plank of the New Order was development, which was to be judged in terms of production, production itself being judged primarily quantitatively and being applicable to anything. You can indeed must - have more tradition, traditional villages and capabilities (the Indonesian was usually ketrampilan, skills, Balinese being identified synecdochically by their legendary skills in the performing and plastic arts) and also increase development and modern skills without any contradiction. The incoherencies of the underlying antagonism of the project of development are obvious. It is 'productivism' gone mad. There is nothing to which it does not apply. It was not just the Governor of Bali, but state television, which was caught up in reiterating an articulation which was at once absurd and hegemonic. Unfortunately it is not the Governor of Bali who is alone in being beguiled by the charms of productivism. I leave it to readers to decide whether their intellectual rears are feeling wet or not.

\section{Production versus seduction}

One of the vocal critics of this festishization of production is Baudrillard, who has opposed production to seduction.

The bourgeois era dedicated itself to nature and production, things quite foreign and even expressly fatal to seduction. And since sexuality arises, as Foucault notes, from a process of production (of discourse, speech or desire), it is not surprising that seduction has been all the more covered over (1990: 1)

Seduction, in Baudrillard's analysis, is emphatically not about sexuality: that articulation was the bourgeois means of tainting the idea of seduction, which belongs to a different world.

Seduction, however, never belongs to the order of nature, but that of artifice never to the order of energy, but that of signs and rituals. This is why all the great systems of production and interpretation have not ceased to exclude seduction - to its good fortune - from their conceptual field (1990: 2).

Seduction is opposed to quantifiability and so to accumulation, power-asproductive and (in a sideswipe at Lacan) the real.

Seduction is stronger than power because it is reversible and mortal, while power, like value, seeks to be irreversible, cumulative and immortal ... It is the emptiness behind, or at the very heart of power and production; it is this emptiness that today gives them their last glimmer of reality. Without

${ }^{22}$ For other examples and an extended analysis, see Hobart 2000. 
that which reverses, annuls, and seduces them, they would never have had the authority of reality. The real, moreover, has never interested anyone. It is a place of disenchantment, a simulacrum of accumulation against death (1990: 46).

Delightfully, even our fascination with structure and systems turns out not to be what it seems.

Any system that is totally complicit in its own absorption, such that signs no longer make sense, will exercise a remarkable power of fascination. Systems fascinate by their esotericism, which preserves them from external logics. The absorption of anything real by something self-sufficient, and self-destructive, proves fascinating (1990: 77).

And nowhere is this submission to ritual more apparent in the modern world than in television, with its repetitive genres and viewing habits. But in the world of media it is in idols and icons, that seduction reaches its peak: in the artificial perfection of the sign.

Undoubtedly the best example of this is to be found in the only important constellation of collective seduction produced by modern times, that of film stars or cinema idols (1990: 94).

Baudrillard offers a persuasive account of the limits of production as the dominant order of modern bourgeois society. But quite what is seduction all about? Nowhere does Baudrillard define seduction, partly of course because definition is an antithetical process to seduction, which stands opposed to production as momentary, reversible, weak, fragile and unstable. It is potentially revolutionary, as it undermines the dominant orders of society - humour and ridicule being examples. It is ritualistic, agonistic, above all linked to artifice, appearances, illusions and the joy of surfaces. Here Baudrillard echoes other writers from Foucault's (1990) scepticism about the claims of interpretation as discovering truth in deep foundations to Sontag (1961) in calling for an appreciation of things as they appear, which significantly she calls an 'erotics'. It is no accident that cartoonists and comedians are among the first targets of authoritarian régimes.

\section{The limits of imagination}

To return to my starting point, the Balinese villagers with whom I have talked over the years about television-watching were perceptive commentators on how the mass media worked in Indonesia. They were acutely aware of the means by which they were being disarticulated. And they were by turns movingly self-critical and detached about how, despite themselves, they could be seduced by television and advertisements (Hobart 
2001). What ordinary people make of, and do with, mass media tends to prove difficult for the over-articulated imaginations of most academics, the very rigorousness of whose training makes thinking outside the confines of accepted institutional practice unnecessary, inappropriate or downright dangerous. We are facing the limits of reifying production - and, equally, distribution and reception - as objects of study.

Such analyses fail to consider the mass media as practices. A stress on practice - and so relationships, because practices by definition relate agents and events - changes our object of study. Practice may be the meeting point between empirical and critical approaches because, significantly, it includes the practices of media practitioners, audiences and the researchers themselves as part of the problem. In so doing it marks a shift from the conventional hierarchy of the knower and her categories as being considered superior to those of the known. Film and television producers, let alone audiences, across Asia are constantly articulating the world in ways most academics have simply never imagined possible, and so have never bothered to inquire about. The result is that they have been deaf to a discours going on all around them every day. It would be sadly facile to carry on dismissing it as just talk.

\section{Bibliography}

Ang, I., (1991) Desperately seeking the audience. London: Routledge.

(1996) Living room wars: Rethinking media audiences in a postmodern world. London: Routledge.

Baudrillard, J., (1970) La société de consommation: ses mythes, ses structures. Paris: Gallimard (1998) The consumer society: myths and structures, trans. C. Turner, London: Sage. - (1983) Simulations. trans. P. Foss, P. Patton \& P. Beitchman, New York: Semiotext(e).

(1990) Seduction. trans. B. Singer, New York: St. Martin's Press; originally 1979, De la séduction. Paris: Editions Galilée.

- (1993) "I don't belong to the club, to the seraglio". In Baudrillard live: selected interviews. ed. M. Gane, London: Routledge.

— (1995) The gulf war did not take place. trans. P. Patton, Sydney: Power Publications. Bocock, R., (1993) Consumption. London: Routledge.

Bourdieu, P., (1977) Outline of a theory of practice. trans. R. Nice, Cambridge: Univ. Press.

Chen, K.-H., (1996) "Post-marxism: between/beyond critical postmodernism and cultural studies", In Stuart Hall: critical dialogues in cultural studies. Eds. D. Morley \& K.-H. Chen, London: Routledge.

Chua, B-H., (with C.Y. Kuo) (1995) "The making of a new nation: cultural construction and national identity", In Communitarian ideology and democracy in Singapore. London: Routledge.

Collingwood, R.G., (1933) An essay on philosophical method. Oxford: Clarendon Press.

— (1940) An essay on metaphysics. Oxford: Clarendon Press.

(1946) The idea of history. Oxford: Clarendon Press. 
Curran, J. \& Park M-J. eds., (2000) Dewesternizing media studies. London \& New York: Routledge.

Erni, J.N. \& Chua, S.K., (2005) Asian media studies: politics of subjectivities. Oxford: Blackwell.

Fiske, J., (1987) Television culture. London: Methuen.

\& Hartley, J., (1978) Reading television. London: Methuen.

Fox, R. n.d. "Forget the appearances! Some thoughts from a Copernican in TV land" www.berubah.org, Accessed 26th December (2005)

Foucault, M., (1970) The order of things: an archaeology of the human sciences. London: Tavistock.

- (1977a) "Intellectuals and power" In Language, counter-memory, practice: selected essays and interviews by Michel Foucault, ed. D.F. Bouchard, Ithaca, N.Y.: Cornell Univ. Press.

(1977b) "Nietzsche, genealogy, history" In Language, counter-memory, practice: selected essays and interviews by Michel Foucault, ed. D.F. Bouchard, Ithaca, N.Y.: Cornell Univ. Press.

(1977c) Discipline and punish: the birth of the prison. trans. A. Sheridan, Harmondsworth: Penguin.

(1980) "What is an author?" In Textual strategies: perspectives in post-structuralist criticism. ed. J.V. Harari, London: Methuen.

(1982) "The subject and power" Afterword to Michel Foucault: beyond structuralism and hermeneutics. eds. H.L. Dreyfus \& P. Rabinow, Brighton: Harvester. (1990) "Nietzsche, Freud, Marx" In Transforming the hermeneutic context: from Nietzsche to Nancy. eds. G.L. Ormiston \& A.D. Schrift, Albany, N.Y.: New York State Univ. Press,

Giddens, A., (1984) The constitution of society: outline of the theory of structuration. Cambridge: Polity Press.

Goodman, N., (1968) Languages of art. Indianapolis: Bobbs-Merrill.

Gramsci, A., (1971) "The Intellectuals" In Selections from the prison notebooks of Antonio Gramsci. eds. \& trans. Q. Hoare \& G. Nowell Smith, London: lawrence \& Wishart. Habermas, J. (1987) The Philosophical Discourse of Modernity: twelve lectures. trans.

F. Lawrence, Cambridge: Polity Press.

Hacking, I., (1990) The taming of chance. Cambridge: Univ. Press.

Hall, S., (1980a) "Cultural studies: two paradigms" Media, culture and society 2: 51-72. (1980) "Encoding/decoding" In Culture, media, language: working papers in cultural studies, 1971-79. eds. S. Hall et al. London: Unwin Hyman.

— (1996) "Cultural studies and its theoretical legacies" In Stuart Hall: critical dialogues in cultural studies, eds. D. Morley, K.-H. Chen, London: Routledge, 261-75. Hartley, J., (1992) Tele-ology: studies in television. London: Routledge. (1999) Uses of television. London: Routledge.

Heider, K.G., (1991) Indonesian cinema: national culture on screen. Honolulu: Univ. of Hawai'i Press.

Hill, D.T., (1994) The press in New Order Indonesia. University of Western Australia Press in association with Asia Research Institute on Social, Political and Economic Change.

Hobart, M., (1990) "The patience of plants: a note on agency in Bali" In Review of Indonesian and Malaysian affairs 24, 2: 91-135.

(1999a) "The end of the world news: articulating television in Bali" In Staying 
local in the global village: Bali in the twentieth century. Eds. R. Rubinstein \& L. Connor, Honolulu: Univ. of Hawai'i Press, 261-289.

- (1999b) "As they like it: Overinterpretation and hyporeality in Bali" In The problem of context. ed. R. Dilley, Oxford: Berghahn, 101-144; available online at www.criticalia.org

(2000) "Introduction" In: After culture: anthropology as radical metaphysical critique Yogyakarta: Duta Wacana Press, 1-53; available online at www.criticalia.org

(2001) "Drunk on the screen: Balinese conversations about television and advertising” In Asian Media Productions. ed. B. Moeran, London: Routledge Curzon. - (2005) "The profanity of the media" In Media Anthropology., eds. E. Rothenbuhler \& M. Coman, London: Sage.

— (forthcoming) "Entertaining illusions: how Indonesian élites imagine the masses through television", Asian journal of communication, special issue eds. M. Hobart \& R. Fox.

Hough, B., (1992) Contemporary Balinese dance spectacles as national ritual. Monash Centre of Southeast Asian Studies, Working Paper 74.

Jenkins, R., (1992) Pierre Bourdieu. London: Routledge.

Kitley, P.T., (1998) Television, nation and culture in Indonesia. Ph.D. thesis in Murdoch University.

Laclau, E., (1990a) "The impossibility of society", In New reflections on the revolution of our time. London: Verso.

(1990b) "New reflections on the revolution of our time" In New reflections on the revolution of our time. London: Verso.

\& Mouffe, C., (1985) Hegemony and socialist strategy: towards radical democratic politics. trans. W. Moore \& P. Cammack, London: Verso.

McGuigan, J., (1992) Cultural populism. London: Routledge.

Morley, D., (1992) Television, audiences and cultural studies. London:Routledge.

Quine, W.V.O., (1953) "Two dogmas of empiricism", In From a logical point of view: nine logico-philosophical essays. Cambridge, Mass.: Harvard Univ. Press.

Schärer, H., (1963) Ngaju religion: the concept of god among a South Bornean People. trans. R. Needham, The Hague: Nijhoff.

Searle, J., (1971) "What is a speech act?" In The philosophy of language. ed. J. Searle, Oxford: Univ. Press.

Sen, K., (1982) "The image of women in Indonesian films: some observations", Prisma 24: 11-29.

Shohat, E. \& Stam, R., (1994) Unthinking Eurocentrism: multiculturalism and the media. London: Routledge.

Sontag, S., (1961) "Against interpretation" In Against interpretation and other essays. New York: Octagon.

Staten, H., (1986) Wittgenstein and Derrida. London: Univ. of Nebraska Press.

Stokes, J., (2000) On screen rivals: cinema and television in the United States and Britain. New York: St. Martin's Press. 